\title{
Feeding ecology and food preferences of Cherok Paloh, Pahang horseshoe crab, Tachypleus gigas
}

\author{
Mohd Razali Md Razak ${ }^{a}$, Zaleha Kassim ${ }^{a^{*}}$, Asnor Azrin Sabuti ${ }^{a}$, Ahmad Ismail ${ }^{\text {b }}$ \\ ${ }^{a}$ Kulliyyah of Science, International Islamic University Malaysia, Jalan Sultan Ahmad Shah, Bandar Indera Mahkota, 25200 Kuantan, Pahang, \\ Malaysia \\ ${ }^{b}$ Department of Biology, Faculty of Science, Universiti Putra Malaysia, 43400 Serdang, Selangor, Malaysia
}

* Corresponding author:drzack@iium.edu.my

\section{Article history}

Received 20 April 2017

Accepted 10 August 2017

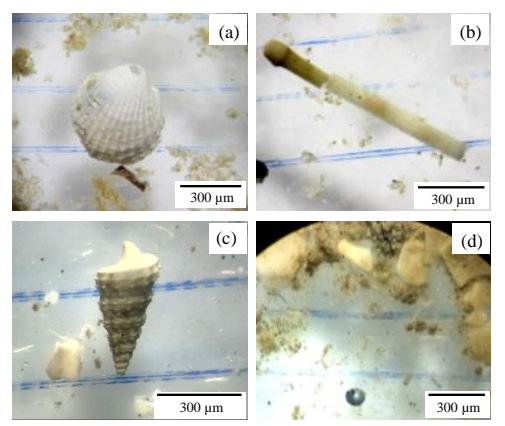

\begin{abstract}
Intensive earlier studies on horseshoe crabs feeding ecology were mostly focused on Limulus polyphemus. Their food preference might be different depend on the availability and abundance of feeds in the particular environment. This paper aims to investigate the feeding ecology and food preferences of Cherok Paloh, Pahang Tachypleus gigas. Ten samples of male and female horseshoe crabs, Tachypleus gigas were trapped in fishing net during the incoming high tide and 20 samples of male and female were hand-harvested at the spawning beach; 10 samples during premating and 10 samples during post-mating. Their gut content was analysed using the Electivity Index. Results showed that Tachypleus gigas coming to spawn with full gut content. Echinoderm served as a main food composition in the gut of males $(50 \%)$ and females $(51.94 \%)$ during the open sea migration phase. The main composition was substituted by macrophyte (males: $59.51 \%$ to $65.15 \%$; females: $36.36 \%$ to $58.10 \%$ ) as they arrived to shore. Based on Electivity Index, male crabs showed positive preference toward polychaete (El: 0.04) and macrophyte (El: 0.19) at the spawning site while, the females showed positive preference toward bivalve (El: 0.46). Further study on feeding ecology is needed in order to improve the population of Tachypleus gigas in Malaysia.
\end{abstract}

Keywords: Tachypleus gigas, electivity index, food composition, gastro-somatic index, spawning migration phase

(C) 2017 Penerbit UTM Press. All rights reserved

\section{INTRODUCTION}

Horseshoe crabs are mysterious chelicerate that extant since 300 million years ago and has virtually unchanged for the past 150 million years (Rudkin and Young, 2009). The capability to adapt with the various environment changes has leaded them to remain in the marine ecosystem for million years. There are only four extant species left and inhabit the realm sympatrically (Tan et al., 2009; Behera et al., 2015). Atlantic species, Limulus polyphemus distribution is limited in the Atlantic region to Delaware (Botton, 1984; Nordstrom et al., 2006; Haramis et al., 2007; Jackson et al., 2007; Niles et al., 2013), Gulf of Mexico (Saunders et al., 1986; Rozihan and Ismail, 2012; Beekey et al., 2013; Vasquez et al., 2015) and Florida (Ehlinger and Tankersley, 2009; Brockmann and Johnson, 2011). Meanwhile, the Asian species, Tachypleus gigas mainly inhabit to China (Hu et al., 2009), Japan (Iwaoka and Okayama, 2009), Malaysia (Zaleha et al., 2010, 2012), Thailand, Singapore, Borneo, Indonesia (Tan et al., 2009), and northern Vietnam besides Sundarbans region (Khan, 2003). According to Manca et al., (2016), horseshoe crabs could be found in estuaries and surf-protected beach during non-monsoon (spawning season). Watson and Chabot (2010) study found that they would remain at the deep sea area passively by burrowing under the sand during monsoon (non-spawning season). Nowadays, horseshoe crabs has emerged as an important resource for the medical purposes (Naqvi et al., 2004; R. A. Fisher and D. L. Fisher, 2006; Gerhart, 2007). In term of ecology, the present of the horseshoe crabs in the ecosystem are vital as associate to connect the energy transfer within coastal food web (Berkson, 2009).

As the omnivorous benthic feeders (Carmichael et al., 2004), prey selection has been identified as horseshoe crab's behaviour during foraging activity (Botton, 1984a; Chatterji et al., 1992). Their feed selection is tend to the benthic community namely; bivalve, polychaete, crustacean, gastropods, and macrophytes (Botton et al., 2003). Walls et al. (2002) study have identified several benthic species inside the gut of the Atlantic horseshoe crabs such as, mollusks including razor clam, macoma clam (Macoma spp.), blue mussel (Mytilus edulis) and worms such as polychaete and nemertean. However, intensive previous studies on feeding ecology of horseshoe crabs were mostly focused on Limulus polyphemus. Study on feeding ecology of the Asian horseshoe crab, Tachypleus gigas by Chatterji et al. (1992) along the Balramgari beach at the Bay of Bengal found that molluscs species was the major food composition in the gut of Tachypleus gigas. However, this food preference might be depend on the availability and abundance of the feed in the particular environment. Botton (1984) and John et al. (2012) studies have supported this assumption where, the differences on food selection of horseshoe crabs would depend on the availability of the feed between seasons and geological areas.

As the population of the Tachypleus gigas species that distributed between Indian Ocean and South China Sea separated by the Malaysian Peninsular barrier, the feeding ecology also might be different. The differences in feeding ecology led Botton (1984) and 
Botton and Haskin (1984) to conduct a serial study on the preference food of Limulus polyphemus that inhabited New Jersey and Delaware beaches respectively during 1984. In addition, Carmichael et al. (2004) study on $\mathrm{N}$ and $\mathrm{C}$ stable isotopic in horseshoe crabs diet composition found that most of the foods inside the gut of horseshoe crabs were not been foraged at the spawning ground. Preference feeds study that conducted by John et al. (2012) determined polychaete as the most preferred food for the Asian species that inhabiting the east coast of Malaysian peninsular but, the study only restricted to the Mangrove species, Carcinoscorpius rotundicauda. Since horseshoe crabs were loyal to their own local foraging ground (Carmichael et al., 2004), study on their gut content could lead to determine their exact foraging ground. Besides that, study on their preference feed is needed for the conservation purposes. Hence, the present study was aimed to investigate the feeding ecology and food preferences of the Tachypleus gigas between male and female by comparing their gut content during the open sea, pre-mating (beach) and post-mating (beach) migration phases at Cherok Paloh, Pahang costal area.

\section{EXPERIMENTAL}

\section{Samples collection site and technique}

Cherok Paloh in Pahang, East coast of Peninsular Malaysia was identified to be the nesting ground of horseshoe crab, Tachypleus gigas. Sampling activities were conducted from October to December, 2016. A total of 30 samples of males and females respectively were used in this experiment. 10 samples of males and females Tachypleus gigas were trapped in fishing net respectively at the open sea area, near to the opening of Cherok Paloh River $\left(03^{\circ} 37^{\prime} 33^{\prime \prime} \mathrm{N} 103^{\circ} 23^{\prime} 16^{\prime \prime} \mathrm{E}\right)$ during the incoming high tide and 20 samples of males and females were handpicked respectively at the nesting ground at Cherok Paloh shoreline (0336'27" N, 10323'36" E) (Fig. 1); 10 samples of males and females were handpicked during pre-mating (before the highest tide) and the other 10 samples were collected during post-mating (after the highest tide) by pulling out of the digging pit. The harvested samples were transported immediately to the Institute of Oceanography and Maritime Studies (INOCEM) facilities. The conditions based on the colour, the present of pitting on the carapace and the present of the body appendages were inspected on each crab samples. Only the perfect condition crabs were used for the gut content analysis. All samples have passed the quality and health inspection. Horseshoe crabs were sexed and their body mass and carapace length were measured. As an ethical purpose, the crabs had been prior killed by leaving in $-20^{\circ}$ refrigerator before dissected. The mortality was monitored for every 1 hour. All samples dead within 2 hours in the refrigerator.

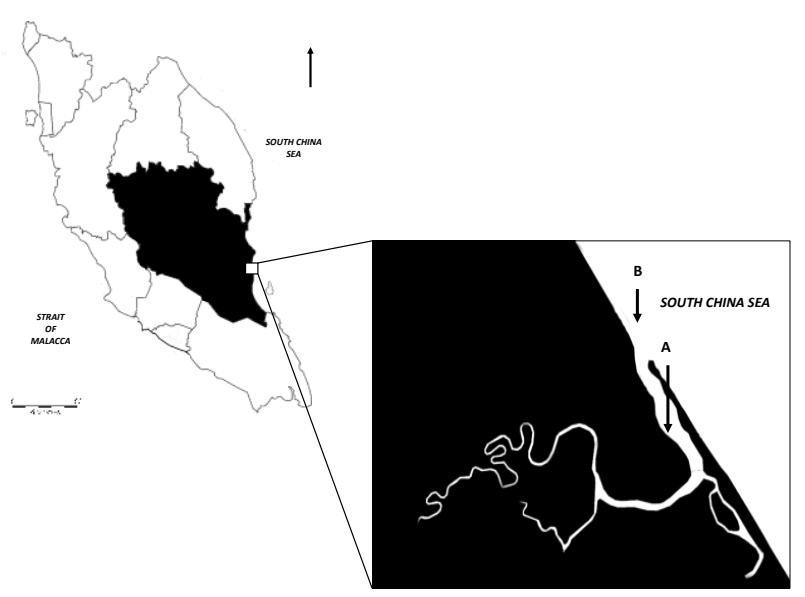

Fig. 1 Locations of Cherok Paloh, Kuantan, Pahang. A: Beach, hand harvesting $\left(03^{\circ} 36^{\prime} 27^{\prime \prime} \mathrm{N}, 103^{\circ} 23^{\prime} 36^{\prime \prime} \quad \mathrm{E}\right)$. B: Open sea, netting $\left(03^{\circ} 37^{\prime} 33^{\prime \prime} \mathrm{N} 103^{\circ} 23^{\prime} 16^{\prime \prime} \mathrm{E}\right)$

\section{Gut content analysis}

The carapace was cut open ventrally from the posterior-ventral region elongated to the edge of prosoma and continued to under the gills until the end of the anterior part of carapace at the opisthosoma region that covering the joint of the telson (Fig. 2) for all collected crabs that stated in previous method. The attached musculature and gonad organs along the gut were cleaned off and the digestive tract from oesophagus to anus was lifted out. Wet weight of the gut was recorded and the foregut and hind gut had been cut off and separated into different petri disc. The digestive tract was cut elongated and opened carefully to avoid disturbance on the gut content. Emptiness of the gut was recorded by measuring the length of the emptied gut tract expressed as percentage of total length of the gut. The contents of the digestive tract then were transferred to $10 \%$ ethanol. Observation was made initially under the low power of a dissecting microscope and the identification process was made according to Squires and Dawe (2003) criteria. The gut contents were identified to a group level; polychaete, crustacean, gastropod, bivalve, echinoderm, macrophyte and miscellaneous. Miscellaneous food items are including foraminifera, insects, amphipods, isopods, annelid worms, larval, and juvenile stages of fishes (John et al., 2012).

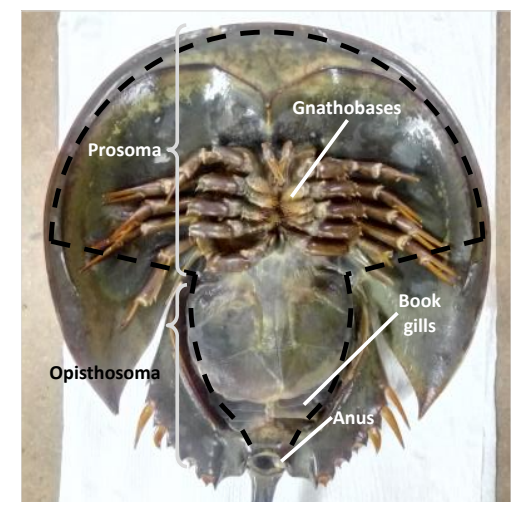

Fig. 2 Dissection track (black dashes line) on prosoma ventral region of Tachypleus gigas.

\section{Benthos analysis}

Sediment samples were collected from the horseshoe crabs' digging pit by the Van Veen grab. Samples were analysed using the Electivity Index (EI) by comparing with the gut compositions of 10 male and female crabs that harvested during post-mating phase at the nesting ground. The samples were sieved through $0.5 \mathrm{~mm}$ mesh size sieve then the remained macrobenthos were collected and preserved in buffered formalin containing Rose Bengal. Identification of the macrobenthos was classed as mentioned in previous method by using a dissecting microscope.

\section{Data analysis}

One way ANOVA test was performed to identify the significant variation of feeding intensity among different spawning migration phases. Electivity index was used to measure the preference of food selection (Ivlev, 1961; Chatterji et al., 1992; John et al., 2012). The values of the electivity index range are between +1 to -1 where, the positive values indicating the higher proportion of the particular food in the gut than found in nature. Meanwhile, the opposite indication would be for the negative values. The calculation of the electivity index $(E I)$ was conducted using following formula:

$$
E=\frac{r_{i}-P_{i}}{r_{i}+P_{i}}
$$

' $r_{i}$ ' is the relative amount of any food item in the gut and ' $P_{i}$ ' the relative abundance of the same food items in environment. Both values were expressed in a percentage of the total amount of food items. The calculation of the gastro-somatic index (Ga.S.I) was conducted using following formula:

Gastro Somatic Index (Ga.S.I) $=\frac{\text { Weight of the stomach }}{\text { Weight of the crab }} \times 100$ 
The feeding intensity was studied by determining the gastrosomatic index (gut weight expressed as percentage of body weight) as described by Chatterji et al. (1977).

\section{RESULTS}

\section{Feeding intensity}

The value of the gastro-somatic index and the percentage of guts emptiness during different spawning migration phase are presented in Fig. 3. There were no significant increases in feeding intensity as the crabs migrated inshore. Present study found that gut fullness of males was lower than females during all three spawning migration phases. However, the decreases of the gut fullness was significantly higher in females $(\mathrm{P}<0.05)$ while, no significant decrease in males $(\mathrm{p}>0.05)$ as they migrated inshore. Their gut fullness depleted $4 \%$ and $20 \%$ in males and females respectively between open sea and post-mating migration phases. Although the gut fullness was lower for male crabs, their gastro-somatic index value were higher than females along the spawning migration $(\mathrm{p}<0.05)$.

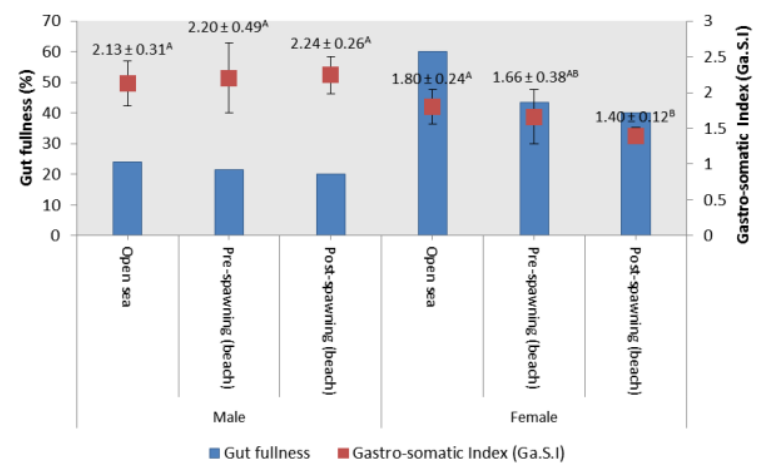

Fig. 3 The gut fullness and gastro-somatic index (Ga.S.I) of male and female crabs that harvested at open sea and during pre and post spawning (beach). Different capital letters within same sex indicate the significant differences $(p<0.05)$.

\section{Food composition}

The food composition between sexes showed that male crabs food composition were less variety compared to females. Only four items; polychaete, bivalve (Fig. 4(a)), echinoderm (Fig. 4(b)(d)) and macrophyte were found in the gut of male crabs while, seven items; crustacean, gastropod (Fig. 4(c)), bivalve, echinoderm, macrophyte and miscellaneous (Fig. 4(d)) in the gut of females. This present study found that echinoderm contributed as a major food composition in the gut of males (50\%) and females (51.94\%) during open sea migration phase then, followed by bivalve that constituted $33.33 \%$ and $19.48 \%$ in gut of males and females respectively. However, the composition of echinoderm and bivalve decreased as the crabs migrated inshore. Opposite observation found on macrophyte where, this food composition increased in the gut of crabs as they migrated inshore. Macrophyte contributed as a major food item; $59.51 \%$ to $65.15 \%$ in the gut of males and $38.36 \%$ to $58.10 \%$ in gut of females within premating and post-mating. As the availability of the polychaete restricted to the shore area, the composition of the polychaete (11.62\%) was found in the gut of male crabs only after the mating ritual (post-mating). Bivalve constituted $27.27 \%$ of food composition in the gut of females during post-mating phase. No gastropods composition was found in the gut of both sexes during post-mating phase. Echinoderm remained in the guts of male and female crabs from the open sea until the post-mating phase (Fig. 5).
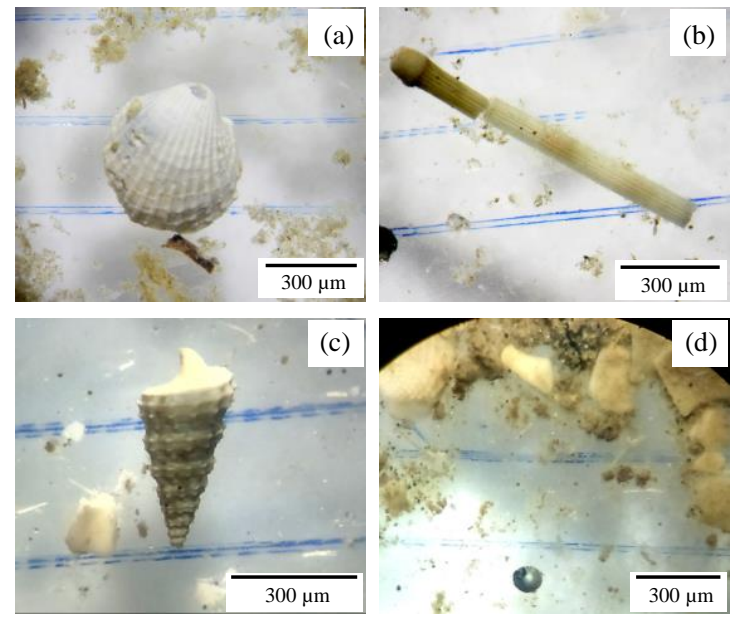

Fig. 4 Photographs of food items found inside the gut of Tachypleus gigas; bivalve (shell) (a), echinoderm (sea urchin spine) (b), gastropod (shell) (c), foraminifera and echinoderm (sea urchin fragments) (d).

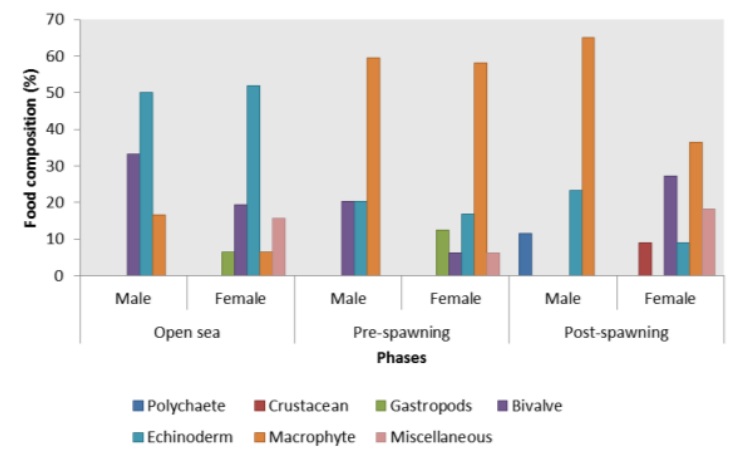

Fig. 5 The food composition inside the gut of male and female horseshoe crabs, Tachypleus gigas.

\section{Food selection}

The Electivity Index $(E I)$ was calculated for the frequent food items in the gut of post-mating T. gigas from October to December, 2016 (Fig. 6). The values of the preference of males during postmating phase were negative $(E I=-1)$ toward crustacean, gastropods, bivalve and miscellaneous, while females were negative toward polychaete $(E I=-1)$, crustacean $(E I=-0.20)$, gastropods $(E I=-1)$ and macrophyte $(E I=-0.08)$. Within mollusc food items, electivity index value showed that females preferred more bivalves $(E I=0.46)$ than gastropods. However, male crabs showed positive selection toward polychaete $(E I=0.04)$ and macrophyte $(E I=0.19)$ as their diet composition. Selections on echinoderms of male and female horseshoe crabs were positive. The Electivity Index value of echinoderms $(E I=1)$ that showed in the result indicated that horseshoe crabs did foraged this food item at the different foraging area than in the spawning site where, there were no echinoderms found in the spawning site sediment.

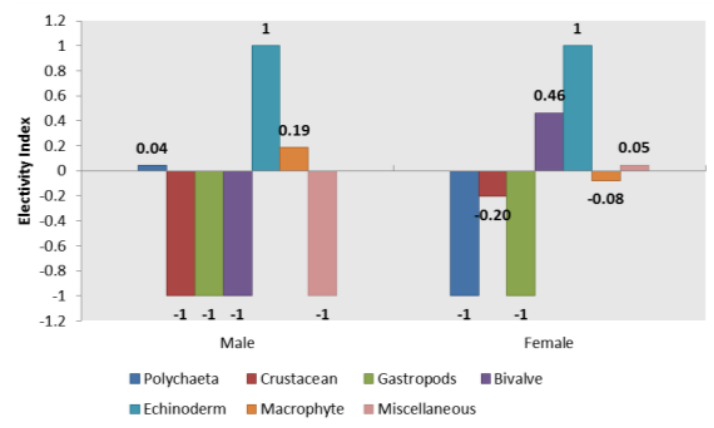

Fig. 6 The electivity indices of different major food items consumed by Tachypleus gigas. 


\section{DISCUSSION}

Feeding intensity of male and female crabs showed no variation between open sea, pre-mating and post-mating migration phase. This resulted by no significant food intake along the inshore spawning migration phases for male and female. Although the gut fullness of males was lower than females, the gastro-somatic indexes values of the male crabs were higher than females for all three phases of migration. This result showed that male crabs have a higher percentage of gut weight expressed of their body mass compared to females. It could be related with the feeding behaviour of the male during amplexus position along the spawning season. According to Brockmann, (2003), male horseshoe crab could amplex onto female up to 51 days. Besides that, their feeding behaviours are restricted during amplexus (Smith et al., 2013) and this would lead the males to have a specific behaviour in order to adapt the restrain by made their stomach as a food "reservoir". In addition, present study found that horseshoe crabs came to spawn with full gut content. However, the content decreased as the horseshoe crab migrated inshore. The decreases were higher in female crabs than males. The gut fullness of females between open sea and post-spawning migration phases decreased dramatically (20\%) compared to males $(4 \%)$. The gut fullness of males was associated by their low digestive enzymatic activity that influenced their satiation and preference toward food during migration (John et al., 2012). Suzuki et al., (1975) and Uys et al., (1987) defined those male crabs might ultimately reduce their digestive enzymatic activities as the adaptation to the restricted feeding ability and less energy requirement during amplexus. Female crabs would spent more energy during the migration inshore against the physiologically stressed gravid conditions. Thus, the assimilation of foods might be higher in purposes to meet the energy requirement during the migration.

The composition of food items in the gut was varied among spawning migration phases. Echinoderms have been identified as a major food composition inside the gut of male and female crabs during the open sea phase and they remained in horseshoe crabs gut until the post-mating phase due to the longer excretion period. Most of the echinoderms that found in crabs' gut were constituted by the echinoidea class; sea urchin. Raja Muda coral reef $\left(3^{\circ} 38^{\prime} 01^{\prime \prime N}\right.$ $103^{\circ} 28^{\prime} 23^{\prime \prime E}$ ) has been identified as the nearest sea urchin habitat to the sampling area. Interesting to state that, sea urchin contributed approximately $38.10 \%$ of benthos composition in Raja Muda coral reef (unpublished data). This analysis showed that horseshoe crabs had conducted their foraging activity before arrived inshore. According to Carmichael et al. (2004) study on $\mathrm{N}$ and C stable isotopic in horseshoe crabs diet composition found that most of the food items that found inside the crabs' gut were not been foraged at the spawning ground. Interestingly, there is no report in previous research paper state about the composition of echinoderm inside the gut of T. gigas. Nevertheless, the main food composition was substituted by macrophyte as the crabs migrated inshore. The gut compositions of horseshoe crabs were closely related by the abundance and availability of food in the environment. The Malaysian peninsular land barrier effect has been shown in various species, including macrophyte (Bachelet et al., 2000; $\mathrm{Ng}$ et al., 2015) and marine animals (Crandall et al., 2008; Fitzpatrick et al., 2011), which depend on the water currents for their dispersal. Even though the feeding intensity of male and female crabs showed no significant increases between open sea and beach (pre-mating and post-mating) migration phases, the new food items namely, polychaete and crustacean that found in the gut of male and female crabs respectively after the spawning ritual (post-spawning) showed that horseshoe crabs did foraged at the beach area.

Electivity Index (EI) study found that male and female crabs highly preferred to consume echinoderm (EI: 1). However, there was no echinoderm found in the spawning ground sediment. Based on the previous food composition analysis, the present of echinoderms in the gut of male and female horseshoe crabs remained from the open sea until the post-mating phase. The present of the echinoderm in the gut would be bias to the electivity index analysis result and could decrease the electivity index value of the other food items. Male crabs positively preferred to forage macrophyte and polychaete while the females preferred more toward bivalve at the spawning ground. Studies on gut content analysis by Botton (1984a), Debnath and Choudhury (1987), Chatterji et al. (1992) and Botton et al. (2003) stated that bivalves may be a main protein component of adult female horseshoe crab diet at the spawning site. The amplexus position may restrict the grasping of food activity (forage) as male are in closer with the female's opisthosoma that may also prevent attached males from extending their genital operculum to remain the foraged food under the gnathobases. Thus, attached males may be restricted to feed only on soft food types that can be grasped by pedipalps and placed directly in the mouth, and then shredded by the proventriculus (Smith et al., 2013). Macrophyte may be a food item that could fulfil such requirements. Besides that, sediment analysis encountered that the composition of macrophyte was higher in the beach area. Similar observations have been reported previously by Botton (1984); Botton and Ropes (1989); Chatterji et al. (1992); Khan (2003); John et al. (2012) that encountered macrophyte was the major food composition in the gut of male horseshoe crabs.

\section{CONCLUSION}

Horseshoe crabs significantly conducted their foraging activity before the spawning migration and came to the shore with full gut content. Females gut fullness was higher than males along the spawning migration phases. However, the gastro-somatic study found that male crabs could have an ability to store a higher food ration in their gut. Besides that, foods would remain in a longer period in males than females as the male crabs have an ability to slow down the enzymatic reaction during the spawning migration. The food composition study showed that echinoderms dominated food item in $T$. gigas' gut during the open sea migration phase and the dominations were substituted by macrophyte as the horseshoe crabs migrated inshore. Nonetheless, echinoderms remained in horseshoe crab's gut along the spawning migration period. At the beach area, male crabs positively preferred polychaete and macrophyte while the females preferred bivalve. Further study on feeding ecology is needed in order to improve the reproductive success and growth of $T$. gigas in Malaysia. Due to the declination of horseshoe crabs population that caused by anthropogenic pressure at the nesting grounds along the Malaysian costal area, a strong legislative step is needed to help in preserving and conserving their population.

\section{ACKNOWLEDGEMENT}

This study was funded by The Ministry of Higher Education Malaysia under the Fundamental Research Grant Scheme (FRGS 2015-2017), FRGS15-199-0440.

\section{REFERENCES}

Bachelet, G., de Montaudouin, X., Auby, I., Labourg, P. J. 2000. Seasonal changes in macrophyte and macrozoobenthos assemblages in three coastal lagoons under varying degrees of eutrophication. Ices Journal of Marine Science: Journal Du Conseil. 57(5), 1495 - 1506.

Beekey, M. A., Mattei, J. H., Pierce, B. J. 2013. Horseshoe crab eggs: a rare resource for predators in long island sound. journal of Experimental Marine Biology And Ecology. 439, 152 - 159. doi.org/10.1016/j.jembe. 2012.11.004

Behera, S., Tripathy, B., Sivakumar, K., Choudhury, B. C., Bhadury, P. 2015. Distribution and abundance of two sympatric species of horseshoe crabs along the Odisha Coast, India. In Carmichael, R. H., Botton, M. L., Shin, P. K. S. and Cheung, S. G (eds.) Changing global perspectives on horseshoe crab biology, conservation and management. New York, London: Springer Cham Heidelberg, $181-191$.

Berkson, J. 2009. An integrative approach to horseshoe crab multiple use and sustainability.. In Tanacredi, J. T., Botton, M. L. and Smith, D. R. (Eds.) Biology and conservation of horseshoe crabs. New York, London: Springer Cham Heidelberg, 387 - 398.

Botton, M. L. 1984. Importance of predation by horseshoe crabs, Limulus polyphemus, to an intertidal sand flat community. Journal of Marine Research. 42, $139-161$. 
Botton, M. L., Haskin, H. H. 1984. Distribution And Feeding ff The Horseshoe Crab, Limulus polyphemus, On The Continental Shelf Off New Jersey. Fishery Bulletin. 82, $383-389$.

Botton, M. L., Ropes, J. W. 1989. Feeding Ecology of Horseshoe Crab On The Continental Shelf, New Jersey To North Carolina. Bulletin Of Marine Science. 49(3), $637-647$.

Botton, M. L., Shuster Jr, C. N., Keinath, J. A. 2003. Horseshoe Crabs In A Food Web: Who Eats Whom? In Shuster, C. N., Barlow, R. B. And Brockmann, H. J. (Eds.) The American Horseshoe Crab. Cambridge, Massachusetts: Harvard Press, $133-153$.

Brockmann, H. J. 2003. Male Competition And Satellite Behavior. In Shuster Jr, C. N., Barlow, R. B. And Brockmann, H. J. (Eds.) The American Horseshoe Crab. Cambridge, Massachusetts: Harvard University Press, $50-$ 82.

Brockmann, H. J., Johnson, S. L. 2011. A Long-Term Study of Spawning Activity In A Florida Gulf Coast Population of Horseshoe Crabs (Limulus polyphemus). Estuaries And Coasts. 34, 1049 - 1067.

Carmichael, R. H., Rutecki, D., Annett, B., Gaines, E., Valiela, I. 2004. Position of Horseshoe Crabs In Estuarine Food Webs: N And C Stable Isotopic Study of Foraging Ranges And Diet Composition. Journal of Experimental Marine Biology And Ecology. 299, 231 - 253.

Chatterji, A., Mishra, J., Parulekar, A. 1992. Feeding Behaviour And Food Selection In The Horseshoe Crab, Tachypleus gigas (Müller) Hydrobiologia. 246(1), $41-48$.

Chatterji, A., Siddiqui, A. Q., Khan, A. A. 1977. Food And Feeding Habits of Labeo Gonius (Ham.) From The River Kali. Journal Bombay Natural History Society. 75, $104-109$.

Crandall, E. D., Frey, M. A., Grosberg, R. K., Barber, P. H., 2008. Contrasting Demographic History And Phylogeographical Patterns In Two Indo-Pacific Gastropods. Molecular Ecology. 17, 611 - 626.

Debnath, R., Choudhury, A. 1987. Studies On Food Preference And Feeding Habit of Horseshoe Crabs (Merostomata: Xiphosura) In The Coastal Waters of West Bengal, India. International Symposium On Tropical Ecology. (11 $16^{\text {th }}$ Dec. 1987). Banaras Hindu Unit, Varanasi, India. 54, $38-39$.

Ehlinger, G. S., Tankersley, R. A. 2009. Ecology of Horseshoe Crabs In Microtidal Lagoons. In Tanacredi, J. T., Botton, M. L. And Smith D. R. (Eds.) Biology And Conservation of Horseshoe Crabs. New York, London Springer Cham Heidelberg, 149 - 162

Fisher, R. A., Fisher, D. L. 2006. The Use of Bait Bags To Reduce The Need For Horseshoe Crab As Bait In The Virginia Whelk Fishery. Gloucester, Virginia: Sea Grant Communications, Virginia Institute of Marine Science. Retrieved from: http://web.vims.edu/adv/fisheries/MRR2006_10.pdf

Fitzpatrick, J. M., Carlon, D. B., Lippe, C., Robertson, D. R., 2011. The West Pacific Diversity Hotspot As A Source Or Sink For New Species? Population Genetic Insights From The Indo-Pacific Parrotfish Scarus Rubroviolaceus. Molecular Ecology. 20, 219 - 234.

Gerhart, S. D. 2007. A Review of The Biology And Management of Horseshoe Crabs, With Emphasis On Florida Populations. Fish And Wildlife Research Institute. Technical Reports. St. Petersburg, FL: Florida Fish and Wildlife Conservation Commission, Fish and Wildlife Research Institute. 12, 1 - 24 Retrieved from: http://aquaticcommons.org/123/

Haramis, G. M., Link, W. A., Osenton, P. C., Carter, D. B., Weber, R. G., Clark, N. A., Teece, M. A., Mizrahi, D. S. 2007. Stable Isotope And Pen Feeding Trial Studies Confirm The Value of Horseshoe Crab Limulus polyphemus Eggs To Spring Migrant Shorebirds In Delaware Bay. Journal of Avian Biology. 38(3), 367 - 376.

Hu, M., Wang, Y., Chen, Y., Cheung, S. G., Shin, P. K. S., Li, Q. 2009 Summer Distribution And Abundance of Juvenile Chinese Horseshoe Crabs Tachypleus tridentatus Along And Intertidal Zone In Southern China Aquatic Biology. 7, 107 - 112

Ivlev, V. S. 1961. Experimental Ecology of The Feeding of Fishes. New Haven: Yale University Press.

Iwaoka, C., Okayama, T. 2009. Public Awareness And Community-Based Conservation For The Horseshoe Crab At Saikai National Park In Nagasaki Prefecture, Japan. In Tanacredi, J. T., Botton, M. L. And Smith, D. R. (Eds.) Biology And Conservation of Horseshoe Crabs. New York, London: Springer Cham Heidelberg, 571 - 583.

Jackson, N. L., Smith, D. R., Tiyarattanachai, R., Nordstrom, K. F. 2007. Evaluation of A Small Beach Nourishment Project To Enhance Habitat Suitability For Horseshoe Crabs. Geomorphology. 89, 172 - 185.

John, B. A., Kamaruzzaman, Y., Jalal, K. C. A., Zaleha, K. 2012. Feeding Ecology And Food Preferences of Carcinoscorpius rotundicauda Collected From The Pahang Nesting Grounds. Sains Malaysiana. 41(7), 855 - 861.
Khan, R. A. 2003. Observations On So-Me Aspects of The Biology of Horseshoe Crab, Carcinoscorpius rotundicauda (Latreille) On Mud Flats Of Sunderban Estuarine Region. In Alfred, J. R. B. (Ed.) Records of The Zoological Survey of India. Kolkata, India: Zoological Survey of India Kolkata, $1-23$.

Manca, A., Mohamad, F., Nelson, B. R., Mohd Sofa, M. F. A., Alia'm, A. A., Ismail, N. 2016. Trailing The Spawning Horseshoe Crab Tachypleus gigas (Müller, 1785) At Designated Natal Beaches On The East Coast of Peninsular Malaysia. Cell Development Biology. 5, 171.

Naqvi, S. B., Mirza, T., Sheikh, D., Abbas, T. 2004. Application of Limulus Amebocyte Lysate (Lal) Test For Detecting Endotoxin (Pyrogen) In Large Volume Parenteral. Journal of Pharmaceutical Sciences. 17(1), 89 - 94.

Ng, W. L., Onishi, Y., Inomata, N., Teshima, K. M., Chan, H. T., Baba, S., Changtragoon, S., Siregar, I. Z., Szmidt, A. E. 2015. Closely Related And Sympatric But Not All The Same: Genetic Variation of Indo-West Pacific Rhizophora Mangroves Across The Malay Peninsula. Conservation Genetics. 16, 137 - 150 .

Niles, L. J., Smith, J., Daly, D., Dillingham, T., Shadel, W., Dey, A., Danihel, M., Hafner, S., Wheeler, D. 2013. Restoration of Horseshoe Crab And Migratory Shorebird Habitat On Five Delaware Bay Beaches Damaged By Superstorm Sandy. Published Electronically. Retrieved from: www.smithjam.com/wp-

content/uploads/2014/03/RestorationReport_112213.pdf

Nordstrom, K. F., Jackson, N. L., Smith, D. R., Weber, R. G. 2006. Transport of Horseshoe Crab Eggs By Waves And Swash On An Estuarine Beach: Implications For Foraging Shorebirds. Estuarine, Coastal And Shelf Science. $70,438-448$.

Rozihan, M., Ismail, E. 2012. Impact of Malaysian Continental Drift On The Genetic Diversity of Horseshoe Crab Inferred Through Mtdna Sequence Analysis. International Journal of Biology. 10, 298 - 302.

Rudkin, D. M., Young, G. A. 2009. Horseshoe Crabs - An Ancient Ancestry Revealed. In Tanacredi, J. T., Botton, M. L. And Smith D. R. (Eds.) Biology And Conservation of Horseshoe Crabs. New York, London: Springer Cham Heidelberg, $25-44$.

Saunders, N. C., Kessler, L. G., Avise, J. C. 1986. Genetic Variation And Geographic Differentiation In Mitochondrial Dna of The Horseshoe Crab, Limulus polyphemus. Genetics. 112, $613-627$.

Smith, M. D., Schrank, H. E., Brockmann, H. J. 2013. Measuring The Costs of Alternative Reproductive Tactics In Horseshoe Crabs, Limulus polyphemus. Animal Behaviour. 85(1), 165 - 173

Squires, H., Dawe, E. 2003. Stomach Contents of Snow Crab (Chionoecetes Opilio, Decapoda, Brachyura) From The Northeast New Found Land Shelf. Journal of Northwest Atlantic Fishery Science. 32, 27 - 38.

Suzuki, K., Shiho, O., Imahori, K. 1975. Fructose-Diphophate Aldolase of Horseshoe Crab (Tachypleus tridentatus). Journal of Biochemistry. 77(2), $281-289$.

Tan, S. G., Adibah, A. B., Liew, P. L. 2009. Isolation of Microsatellites Using 5' Anchored Pcr For The Horseshoe Crab Tachypleus gigas And Carcinoscorpius rotundicauda In Malaysia. In Zilfalil, A. Tan, S. G. And Vijay, K. (Eds.) Genetik. Selangor, Mal: Bulletin Pgm, 3 - 5.

Uys, W., Hecht, T., Walters, M. 1987. Changes In Digestive Enzyme Activities of Clarias gariepinus (Pisces: Clariidae) After Feeding. Aquaculture. 63(1-4), 243 - 250

Vasquez, C. M., Johnson, S. L. Brockmann, H. J., Julian, D. 2015. Nest Site Selection Minimizes Environmental Stressor Exposure In The American Horseshoe Crab, Limulus polyphemus (L.). Journal of Experimental Marine Biology And Ecology. 463, 105 - 114.

Walls, E., Berkson, J., Smith, S. A. 2002. The Horseshoe Crab, Limulus polyphemus: 200 Million Years of Existence, 100 Years of Study. Reviews In Fisheries Science. 10(1), 30 - 73.

Watson, W. H., Chabot, C. C. 2010. High Resolution Tracking of Adult Horseshoe Crabs Limulus polyphemus In A New Hampshire Estuary Using Fixed Array Ultrasonic Telemetry. Journal of Current Zoology. 56(5), $599-$ 610.

Zaleha, K., John, B. A., Erni-Atika, H., Kamaruzzaman, B. Y., Jalal, K .C. A. 2012. Spawning And Nesting Behaviour of Tachypleus gigas Along The East Coast of Peninsular Malaysia. International Journal of Biology. 4, 102 $-111$

Zaleha, K., Kamaruzzaman, B. Y., John, B. A., Ong, M. C. 2010. Cd, Cu And $\mathrm{Pb}$ Concentration Levels In Horseshoe Crab Nesting Grounds of Pahang Coast, Malaysia. Journal of Biological Sciences. 10, 790 - 794. 